Article

\title{
Land Application of Urban Horizontal Directional Drilling Residuals to Established Grass and Bare Soils
}

\author{
Joshua Daniel ${ }^{1}$, Chad Penn ${ }^{2, *} \mathbb{C}$, João Antonangelo ${ }^{1}{ }^{\mathbb{D}}$ and Hailin Zhang ${ }^{1} \mathbb{( \mathbb { C }}$ \\ 1 Plant and Soil Sciences Department, Oklahoma State University, Stillwater, OK 74075, USA; \\ josh.daniel14@gmail.com (J.D.); joao.antonangelo@okstate.edu (J.A.); hailin.zhang@okstate.edu (H.Z.) \\ 2 USDA Agricultural Research Service, National Soil Erosion Research Laboratory, 275 South Russell Street, \\ West Lafayette, IN 47907-2077, USA \\ * Correspondence: chad.penn@usda.gov; Tel.: +1-765-494-0330
}

Received: 30 October 2020; Accepted: 8 December 2020; Published: 9 December 2020

\begin{abstract}
Horizontal directional drilling (HDD) is a non-invasive alternative to trenching used for the installation of many common utilities. The process involves drilling fluid used to stabilize the borehole, lubricate the bit, and float cuttings to the surface. A sustainable alternative to landfill disposal is land application. Two field studies were conducted to determine the optimum application rate of HDD residuals to both established bermudagrass and bare soil seeded with bermudagrass. Residuals were applied at six rates ranging from 0 to 112 tons solid ha ${ }^{-1}$ for both trials. Soils were sampled 7, 30, and 90 days after application. Saturated paste and Mehlich-3 extractions were performed on all samples. Grass biomass was measured at the end of the study. No significant amount of nutrients or trace metals were found in the treated soils. All concentrations were in the range of typical soils. However, total dissolved solids (TDS) and sodium absorption ratio (SAR) increased with application rate. There was no significant difference in the yields of forage harvested on the established grass plots 110 days after application. Bare plots that received 22 tons solid ha ${ }^{-1}$ had higher percent ground cover than other rates. It is ecologically safe to apply HDD residuals up to 112 tons and 90 tons solid $\mathrm{ha}^{-1}$ to established bermudagrass and bare soil, respectively.
\end{abstract}

Keywords: residuals; horizontal directional drilling; land application; soil; bermudagrass

\section{Introduction}

In the last three decades, there have been many scientific studies generating a great deal of information on the benefits and environmental impacts associated with the land application of many types of residuals [1]. There are typically two criteria used to assess residuals' "suitability" for land application and whether or not the intended use will be beneficial: (i) the by-product's ability to enhance, or have no negative impact, on the productivity of the soil and plant growth, and (ii) a lack of negative environmental impacts [2]. Because residuals differ so much in their physical, chemical, and biological properties [2], each material should be examined independently for potential beneficial or negative impacts.

There are many by-products that are currently being land-applied. With the recent boom in oil and gas activity in Oklahoma, the land application of spent oil and gas drilling mud has become a very popular method of disposal [3,4]. Adverse environmental impacts on both soil and plant growth after the land application of oil and gas drilling fluid may occur due to the high concentrations of soluble salts, which are found primarily in water-based mud. Biosolids are another by-product commonly land-applied since they contain both organic and inorganic plant-available nutrients as well as soil conditioning properties, giving incentives for its use as a source of fertilizer [5-7]. Another industrial by-product commonly land applied is fly ash from coal-generated power plants. Due to the abundance 
of basic mineral elements resembling the Earth's crust, fly ash is an excellent replacement for natural materials used worldwide [8-10]. However, the application of fly ash to agricultural land cannot supply crops with the macronutrients nitrogen $(\mathrm{N})$ or phosphorus $(\mathrm{P})$ and it can contain different amounts of trace metals such as arsenic $(\mathrm{As})$, copper $(\mathrm{Cu})$, nickel $(\mathrm{Ni})$, lead $(\mathrm{Pb})$, chromium $(\mathrm{Cr})$, and zinc $(\mathrm{Zn})$, which does put a limit on its potential use as a soil amendment [11,12].

In contrast to animal manure, biosolids, and fly ash, much less is known about the composition and potential impact of land application of urban horizontal directional drilling (HDD) residuals. Today there is growing speculation about HDD residuals and the safety of their constituents and chemical makeup. They are often confused with "drilling mud" from the oil and gas industry even though the two by-products are very different. There is a need to separate the public's perception of the spent HDD drilling residuals from that of the oil and gas industry. The cost of transporting spent residuals (sometimes long distances) to landfills and for land application is an economic and temporal burden even when potential areas are close to the drilling site. In a survey conducted in the aforementioned study, some contractors reported the need to dispose of over 100 metric tons of spent HDD residuals per week.

As the interest in land application increases so does public speculation on potential contaminants and, unfortunately, no attention is given to the disposal of HDD residues as a potentially sustainable way to improve agricultural lands without harm to the environment. In the U.S., the regulations and bylaws for the proper disposal of HDD residues vary only by municipality and state since they are not federally regulated [13]. Additionally, while rules for disposal of oil and gas drilling residuals exist in the country, no regulations or guidelines are currently available for HDD residues [13]. To date, there is no published research on the use of spent HDD residuals or their environmental impact as a medium for land application [13].

In a previous study, 58 different HDD residuals from uncontaminated sites across 26 states were characterized in terms of their physical and chemical makeup [13] and presented a wide variation regarding their properties regardless of the location sampled. The analysis included: solids content, electrical conductivity (EC) and $\mathrm{pH}$ of the "as is" residual portion, total soluble salts, water-soluble constituents, and $\mathrm{pH}$ of the separated water portion, and total metals, sodium absorption ratio (SAR), Mehlich-3 extractable elements, Synthetic Precipitation Leaching Procedure (SPLP), and total carbon:total nitrogen of the separated solids portion. Results of all the analyses were compared to different standards for soils, surface waters, and groundwater in order to determine if land application would be a safe method of disposal for the spent HDD residuals. That study [13] found that there was low potential for the residuals to contain anything that would be chemically limiting for land application of residuals, although some samples had elevated levels of total dissolved solids (TDS) and sodium $(\mathrm{Na})$. The $\mathrm{Na}$ and TDS may have originated from some of the ingredients in the drilling fluid or the subsoil that was being drilled at the site. Total solids were found to potentially be the most limiting factor.

For land application to be a viable option for the disposal of spent HDD residuals, more research is needed in order to determine any impacts these residuals might have on the soil and vegetation receiving them. With solids potentially being the most limiting factor for land application, proper application rates need to be determined in order to minimize any potential negative environmental impact. There are two likely scenarios to consider when deciding where HDD residuals might be land applied; on a bare soil at a construction site or a grass cover. HDD is typically produced in a municipal setting or at a construction site. In a municipal setting, a contractor would likely find the nearest pasture or field to land apply the spent residual. In a situation where boring is done on a construction site, the contractor prefers to leave it onsite because the soil is typically already bare. Thus, the objective of this research was to determine proper application rates at which HDD residuals may be applied with minimal environmental and agronomic impact to the soil and vegetation, for both established grass plots and bare soils where the grass is to be established. 


\section{Materials and Methods}

\subsection{Field Location and Soil Description}

The field studies were conducted on a hay field approximately $5 \mathrm{~km}$ northwest of Stillwater, OK (USA). The soil was a Zaneis clay loam (fine-loamy, siliceous, active, thermic Udic Argiustolls), a well-drained soil developed on slopes ranging from $0-8 \%$. The dominant forage was bermudagrass (Cynodon dactylon). The mean annual precipitation is $86.36 \mathrm{~cm}$. The field study included the establishment and monitoring of two field trials upon which HDD residuals were applied to both established grass and bare soils at six different application rates.

\subsection{HDD Fluid}

Before obtaining the HDD residuals, the correct drilling fluid used in HDD operations was recommended by the local dealer according to the soil conditions while helping operators to meet safety regulations. The most effective fluid conditions (viscosity and composition) for a given soil condition were established, monitored, and maintained throughout the drilling process. The drilling fluid was sampled and tested daily. A third-party mud engineer provided recommendations regarding maintenance of the fluid/mud composition. The MSDS for the drilling fluid products were included with the drilling fluids proposal (MSDS sheets are available upon request for reference).

According to the "Fluid Control Plan", if the material was deemed unacceptable due to potential threat to the surrounding environment (if seepage should occur) a new material was selected. Thus, all subsequent drilling fluid materials were subjected to identical review and approval by the client. Generally, the drilling fluid selected for use is formulated so that it does not present an imminent threat to water quality or the aquatic environment. Bentonite, for example, one of the major fluid components, is non-toxic, and an inert substance that meets NSF/ANSI-60 Drinking Water Additive Standards and is frequently used for drilling potable water wells. Therefore, the selection of appropriate materials for the drilling fluid was done in a manner that ecological resources are not negatively affected. Not only the fluid but all products used for drilling operations were used from a client's approved list. If any additional products not on the list are proposed, the subcontractor must submit a request for approval before use.

\subsection{HDD Residues}

The residues were properly stored indoors in ideal storage conditions packaged in pails in dry, clean, and well-ventilated areas under ambient warehouse temperature and away from heat sources. Residuals were then moved from the local contractor and transported to the site using a Ditch Witch MV800 vacuum excavator and transferred into a $3785 \mathrm{~L}$ mixing tank. The residuals were mixed for approximately $20 \mathrm{~min}$ prior to acquiring a sub-sample for all analyses to be performed. Solids content (gravimetric) were separated according to Daniel et al., 2020 [13]. All methods used for the separated solid and liquid fractions physicochemical analyses can be found in Daniel et al., 2020 [13].

\subsection{Experimental Design and Treatments Description}

Individual plot dimensions were $3.05 \times 3.05 \mathrm{~m}$ with $4.6 \mathrm{~m}$ alleys. Each plot received residuals representing $0,22,45,67,90$, or 112 metric tons of solid ha ${ }^{-1}$. Each application rate was replicated three times resulting in 18 experimental units for each study. A scheme is presented in Figure S1 (Supplementary Materials). Residual application rates on the soil surface were achieved by applying the slurry, which had a known solids content, through a hose for various calculated time periods as a function of the calibrated and pre-determined flow rate.

For the established grass field study, plots were sampled 0, 7, 30, and 93 days after application. For the bare soil field study, plots were sampled 0, 7, 29, and 96 days after application. Soil samples were separated by depth, $0-5$ and 5-15 cm. Samples were then dried in an oven for approximately $48 \mathrm{~h}$ and ground using a Bico Soil Pulverizer. 


\subsection{Soil Analyses}

Saturated paste extractions were performed on every sample using $150 \mathrm{~g}$ of dried sample and deionized (DI) water. After mixing, samples equilibrated for one hour before extraction. Samples were extracted using a Baroid pneumatic soil press. Analytes were measured for $\mathrm{Na}$, calcium $(\mathrm{Ca})$, magnesium $(\mathrm{Mg})$, potassium $(\mathrm{K})$, sulfur $(\mathrm{S})$, boron $(\mathrm{B}), \mathrm{P}$, iron $(\mathrm{Fe}), \mathrm{Zn}, \mathrm{Cu}$, manganese $(\mathrm{Mn})$, aluminum (Al), Ni, molybdenum (Mo), As, barium (Ba), cadmium (Cd), cobalt $(\mathrm{Co}), \mathrm{Cr}$, and $\mathrm{Pb}$ via inductively coupled plasma atomic spectroscopy (ICP). Electrical conductivity (EC) and $\mathrm{pH}$ were also measured on each extract using standard $\mathrm{EC}$ and $\mathrm{pH}$ meters.

Mehlich-3 (M3) extractions were conducted to assess plant-available K, P, Mg, Ca, Mn, and Fe using a soil to solution ratio of 1:10 (Mehlich, 1984). Samples were equilibrated for five minutes followed by filtration with No. 42 Whatman paper $(2.5 \mu \mathrm{m}$ for particle retention). Concentrations in extracts were quantified using an ICP.

\subsection{Established Grass Plots}

To simulate a typical hay pasture, plots were mowed before residuals application on the soil surface. The incorporation via mechanical operation would be harmful to the established grass plots because roots would be highly disturbed, and therefore damaged. In a typical hay pasture, forage regrowth occurs after mowing, which can be only achieved when there is an established root system. It is a common agricultural practice for surface application of amendments (such as fertilizers) after mowing to improve forage stands during regrowth because roots might not have all the nutritional reserve needed for good regrowth. Thus, the broadcast application was carried out on the soil surface as many sustainable agricultural practices (such as liming and fertilization) that aim the minimum tillage and organic matter maintenance. In addition, mechanical incorporation would disturb soil structure and promote erosion. A Carter harvester was used to harvest forage to determine biomass approximately 120 days after residual application. Forage was then dried in an oven for approximately $48 \mathrm{~h}$ then ground using a Fritsch Pulverisette 19. Forage was digested using concentrated $\mathrm{HNO}_{3}$ and a heating block. Digests were analyzed for $\mathrm{Ca}, \mathrm{P}, \mathrm{Na}, \mathrm{Mg}, \mathrm{K}, \mathrm{S}, \mathrm{Mn}, \mathrm{Cu}, \mathrm{Fe}$, and $\mathrm{Zn}$ with ICP.

\subsection{Bare Soil Plots}

For the bare soil field study, the upper thatch layer was removed to create a harsher environment with little to no organic matter for establishing seeds. Therefore, the vegetation and the upper $2 \mathrm{~cm}$ of topsoil were removed with a skid steer loader. Before the surface application of residuals, every plot was seeded with Sta-Green bermudagrass seed (Spectrum Brands Middleton, WI, USA). A rotary spreader was used to spread the seed at the application rate of $1.15 \mathrm{~kg}$ of pure live seed per $93 \mathrm{~m}^{2}$. Percent cover was calculated at day 29 and 63 using a digital camera and SamplePoint software. Three pictures were randomly taken within each plot. To standardize the photos, pictures were taken using a pole with a camera mount approximately $100 \mathrm{~cm}$ above the ground surface. One hundred evenly spaced pixels on each picture were manually determined to either have cover or no cover. Values for all three pictures were then averaged to obtain an overall percent cover for the entire plot.

\subsection{Statistical Analysis}

Soil chemical data, forage biomass, and percent cover was analyzed using SAS (SAS Institute, 2002). An ANOVA model of the response variables were created using the PROC GLM routine. The ANOVA model used application rate, time, depth, and replications as treatment effects. Type III least-square means from the PROC GLM routine were used for mean separation tests using the PDIFF option. Mean separation for all treatments were considered significant at the $p<0.05$ level. 


\section{Results and Discussion}

\subsection{Background Soil Properties}

The M3 [14] soil tests for the established grass plots indicated P was 99 to $75 \%$ sufficient for bermudagrass with concentrations ranging from 8 to $30 \mathrm{mg} \mathrm{kg}^{-1}$ at depths of $0-5$ and $5-15 \mathrm{~cm}$. Soil tests for $\mathrm{K}$ indicated 100 to $92 \%$ sufficient for bermudagrass with concentrations of 96 to $186 \mathrm{mg} \mathrm{kg}^{-1}$ at the two depths. Soil tests for the bare soil plots indicated that P was 99 to $100 \%$ sufficient for bermudagrass with concentrations ranging from 31 to $38 \mathrm{mg} \mathrm{kg}^{-1}$ at the two depths. Soil tests for K indicated 83 to $90 \%$ sufficiency for bermudagrass with concentrations 73 to $91 \mathrm{mg} \mathrm{kg}^{-1}$ for the two depths.

\subsection{Physicochemical Properties of HDD Residues}

The residuals applied to the established grass plots had a solids content of 39\%, and an EC, $\mathrm{pH}$, and SAR of $1049 \mu \mathrm{S} \mathrm{cm} \mathrm{cm}^{-1}, 8.2$, and 16, respectively. In the separated water portion, Na was the most abundant constituent at $334.2 \mathrm{mg} \mathrm{L}^{-1}$. In the separated solids portion, $\mathrm{Mn}$ was found to be the highest concentration at $1444 \mathrm{mg} \mathrm{kg}^{-1}$. Mehlich-3 extractable Ca was very high at $28,526 \mathrm{mg} \mathrm{kg}^{-1}$.

Residuals applied to the bare soil plots had a solids content of $28 \%$ and an EC, $\mathrm{pH}$, and SAR of $5417 \mu \mathrm{S} \mathrm{cm}^{-1}, 8.0$, and 19, respectively. Like the residual applied to the established grass plots, Na was the most abundant constituent in the separated water portion at $1224.6 \mathrm{mg} \mathrm{L}^{-1}$. In the separated solids portion, Mn was found to have the highest concentration at $92 \mathrm{mg} \mathrm{kg}^{-1}$. Of the Mehlich-3 extractable elements $\mathrm{Ca}$ was the highest, however much lower than in the residuals applied to the established grass plot, with a concentration of $3766 \mathrm{mg} \mathrm{kg}^{-1}$. All chemical and physical properties of the residuals applied to the established grass and bare soil plots are shown in Table 1.

Table 1. Physicochemical characterization of "as is", separated water portion, and separated solids portion of horizontal directional drilling (HDD) residuals applied to established grass plots and bare soils.

\begin{tabular}{|c|c|c|c|}
\hline Parameter & Unit & Grass Plots & Bare Soils \\
\hline & \multicolumn{2}{|c|}{-_"as is" } & \\
\hline $\mathrm{EC}$ & $\mu S \mathrm{~cm}^{-1}$ & 1049 & 5417 \\
\hline $\mathrm{pH}$ & NA & 8.2 & 8 \\
\hline \multirow{2}{*}{$\begin{array}{l}\text { Solids } \\
\text { Content }\end{array}$} & $\%$ & 39 & 28 \\
\hline & \multicolumn{2}{|c|}{-Separated Water Portion- } & - \\
\hline $\mathrm{EC}$ & $\mu S \mathrm{~cm}^{-1}$ & 1474 & 6775 \\
\hline $\mathrm{pH}$ & NA & 8.4 & 8 \\
\hline SAR & NA & 16 & 19 \\
\hline $\mathrm{Na}$ & $\mathrm{mg} \mathrm{L}^{-1}$ & 334.2 & 1224.6 \\
\hline $\mathrm{Ca}$ & $\mathrm{mg} \mathrm{L}^{-1}$ & 22 & 193.5 \\
\hline $\mathrm{Mg}$ & $\mathrm{mg} \mathrm{L}^{-1}$ & 6.1 & 6.1 \\
\hline $\mathrm{Cu}$ & $\mathrm{mg} \mathrm{L}^{-1}$ & $<\mathrm{LOD}^{\dagger}$ & $<\mathrm{LOD}$ \\
\hline $\mathrm{Zn}$ & $\mathrm{mg} \mathrm{L}^{-1}$ & $<\mathrm{LOD}$ & $<$ LOD \\
\hline Mo & $\mathrm{mg} \mathrm{L}^{-1}$ & 0.06 & 0.04 \\
\hline As & $\mathrm{mg} \mathrm{L}^{-1}$ & 0.03 & $<$ LOD \\
\hline $\mathrm{Cd}$ & $\mathrm{mg} \mathrm{L}^{-1}$ & $<\mathrm{LOD}$ & $<\mathrm{LOD}$ \\
\hline $\mathrm{Co}$ & $\mathrm{mg} \mathrm{L}^{-1}$ & $<\mathrm{LOD}$ & $<$ LOD \\
\hline $\mathrm{Cr}$ & $\mathrm{mg} \mathrm{L}^{-1}$ & 0.02 & 0.01 \\
\hline \multirow[t]{2}{*}{$\mathrm{Pb}$} & $\mathrm{mg} \mathrm{L}^{-1}$ & $<\mathrm{LOD}$ & $<\mathrm{LOD}$ \\
\hline & ated Solids & $\mathrm{n}$-total diges & \\
\hline $\mathrm{Cu}$ & $\mathrm{mg} \mathrm{kg}^{-1}$ & 8 & 7 \\
\hline $\mathrm{Zn}$ & $\mathrm{mg} \mathrm{kg}^{-1}$ & 13 & 18 \\
\hline $\mathrm{Mn}$ & $\mathrm{mg} \mathrm{kg}^{-1}$ & 1444 & 92 \\
\hline $\mathrm{Ni}$ & $\mathrm{mg} \mathrm{kg}^{-1}$ & 6 & 5 \\
\hline
\end{tabular}


Table 1. Cont.

\begin{tabular}{cccc}
\hline $\mathrm{As}$ & $\mathrm{mg} \mathrm{kg}^{-1}$ & $<\mathrm{LOD}$ & $<\mathrm{LOD}$ \\
$\mathrm{Cd}$ & $\mathrm{mg} \mathrm{kg}^{-1}$ & $<\mathrm{LOD}$ & $<\mathrm{LOD}$ \\
$\mathrm{Cr}$ & $\mathrm{mg} \mathrm{kg}^{-1}$ & 7 & 7 \\
$\mathrm{Ba}$ & $\mathrm{mg} \mathrm{kg}^{-1}$ & 34 & 84 \\
$\mathrm{~Pb}$ & $\mathrm{mg} \mathrm{kg}^{-1}$ & $<\mathrm{LOD}$ & $<\mathrm{LOD}$ \\
$\mathrm{Co}$ & $\mathrm{mg} \mathrm{kg}^{-1}$ & 2 & 3 \\
\hline $\mathrm{K}$ & $\mathrm{mg} \mathrm{kg}$ & \\
$\mathrm{P}$ & $\mathrm{mg} \mathrm{kg}^{-1}$ & 81 & 149 \\
$\mathrm{Mg}$ & $\mathrm{mg} \mathrm{kg}^{-1}$ & 367 & 4 \\
$\mathrm{Ca}$ & $\mathrm{mg} \mathrm{kg}^{-1}$ & 28,526 & 599 \\
$\mathrm{Mn}$ & $\mathrm{mg} \mathrm{kg}^{-1}$ & 221 & 3766 \\
\hline \multicolumn{4}{r}{${ }^{\dagger}$ Below limit of detection (LOD). NA: not applicable. }
\end{tabular}

The considerable wide range of solid contents from the residues used ( 28 to $39 \%$ ) is likely due to the variability of the original drilling fluid used and the various formations or sub-soils being bored through [13]. HDD residuals are generally subsoils mixed with some additives originally used in the drilling fluid, as previously highlighted in Daniel et al. (2020) [13], who found an even wider range for the $58 \mathrm{HDD}$ residues analyzed (4 to $72 \%$ ).

\subsection{Established Grass Plots}

\subsubsection{Soil}

Considering all sampling times, the mean $\mathrm{pH}$ ranged from 6.3-8.0 in the top $5 \mathrm{~cm}$ of soil and 6.7-7.9 at the 5-15 cm depth (Table 2). Application rate, time, and depth were all significant with an interaction between depth and time at $p=0.05$. The residuals applied to each plot had a $\mathrm{pH}$ of 8.2 so an increase in $\mathrm{pH}$ in the $0-5 \mathrm{~cm}$ soil with an increase in application rate was plausible but was only statistically significant at day 93.

Table 2. Mean $\mathrm{pH}$ at 7, 30, and 93 days after application of HDD residuals to established grass plots as a function of application rate, soil depth, and sampling time.

\begin{tabular}{ccrc}
\hline Application Rate & Day $\mathbf{7}$ & Day $\mathbf{3 0}$ & Day $\mathbf{9 3}$ \\
\hline (metric tons solid ha $^{\mathbf{- 1}}$ ) & \multicolumn{3}{c}{$-0-5 \mathrm{~cm}-$} \\
0 & $7.5 \mathrm{Aa}$ & $6.3 \mathrm{Ab}$ & $7.0 \mathrm{Ba}$ \\
22 & $7.8 \mathrm{Aa}$ & $6.4 \mathrm{Aa}$ & $7.5 \mathrm{Aa}$ \\
45 & $7.6 \mathrm{Aa}$ & $6.6 \mathrm{Ab}$ & $7.5 \mathrm{Aa}$ \\
67 & $7.7 \mathrm{Aa}$ & $6.4 \mathrm{Ab}$ & $7.4 \mathrm{Aa}$ \\
90 & $7.9 \mathrm{Aa}$ & $6.5 \mathrm{Ab}$ & $7.5 \mathrm{Aa}$ \\
112 & $8.0 \mathrm{Aa}$ & $6.9 \mathrm{Aa}$ & $7.6 \mathrm{Aa}$ \\
& $7.1 \mathrm{Aa}$ & $7.1 \mathrm{Ca}$ & $6.7 \mathrm{Ca}$ \\
0 & $7.9 \mathrm{Aa}$ & $7.2 \mathrm{BCa}$ & $7.6 \mathrm{Aa}$ \\
22 & $7.7 \mathrm{Aa}$ & $7.1 \mathrm{Ca}$ & $7.3 \mathrm{ABa}$ \\
45 & $7.9 \mathrm{Aa}$ & $7.3 \mathrm{BC}$ & $7.2 \mathrm{Ba}$ \\
67 & $7.8 \mathrm{Aa}$ & $7.8 \mathrm{Aa}$ & $7.2 \mathrm{Ba}$ \\
90 & $7.7 \mathrm{Aa}$ & $7.6 \mathrm{ABa}$ & $7.7 \mathrm{Aa}$ \\
\hline 112 &
\end{tabular}

Uppercase letters represent the mean separation between application rates within the depth. Lower case letters represent the mean separation between depths within the application rate $(p=0.05)$. Means with different letters are different at $p<0.05$ level among columns (uppercase letters) and rows (lowercase letters).

As expected, the addition of residuals to the established grass increased the EC of the receiving soil as the application rate increased, with a mean EC range of $463-748 \mu \mathrm{S} \mathrm{cm}^{-1}$ averaged over depth and time. Application rate, time, and depth were all statistically significant. Soil EC for application rates of 
67,90 , and 112 metric tons solid $\mathrm{ha}^{-1}$ averaged across depth and sample time, were significantly higher than the control (Table 3). Soil EC was also significantly different between depths with a mean EC of $887 \mu \mathrm{sm}^{-1}$ in the $0-5 \mathrm{~cm}$ depth and $420 \mu \mathrm{S} \mathrm{cm}^{-1}$ at the 5-15 $\mathrm{cm}$ depth (data not shown). The EC of the residual applied was $1049 \mu \mathrm{S} \mathrm{cm}^{-1}$ so an increase in EC in the $0-5 \mathrm{~cm}$ layer with an increase in application rate was expected. Over the 93-day sampling period $23.6 \mathrm{~cm}$ of precipitation was received, however, no significant leaching of salts was observed. This could be a result of the extreme heat coupled with the upward movement of soil moisture between rain events, wicking salts back up in the profile.

Table 3. Soil electrical conductivity (EC) and Mehlich-3 extractable Ca of established grass plots, and $\mathrm{pH}$ of bare soils after application of HDD residuals at six rates.

\begin{tabular}{|c|c|c|c|c|c|c|c|}
\hline \multirow{2}{*}{ Field } & \multirow{2}{*}{ Depth (cm) } & \multicolumn{6}{|c|}{ Application Rate of HDD Residuals (Metric Tons Solid ha ${ }^{-1}$ ) } \\
\hline & & 0 & 22 & 45 & 67 & 90 & 112 \\
\hline \multirow{6}{*}{ Grass plots } & & \multicolumn{6}{|c|}{$-\mathrm{EC}\left(\mu \mathrm{S} \mathrm{cm}^{-1}\right)^{\dagger}$} \\
\hline & 0-15 & $463 \mathrm{~B}$ & $594 \mathrm{BA}$ & $625 \mathrm{BA}$ & $721 \mathrm{~A}$ & $748 \mathrm{~A}$ & $745 \mathrm{~A}$ \\
\hline & & & & $-\mathrm{Ca}(\mathrm{m}$ & $\left.\mathrm{g}^{-1}\right)^{++}$ & & \\
\hline & $0-5$ & $1459 \mathrm{Ca}$ & $4181 \mathrm{Ba}$ & $4303 \mathrm{Ba}$ & $5141 \mathrm{Ba}$ & 6677 BAa & $7672 \mathrm{Aa}$ \\
\hline & $5-15$ & $1012 \mathrm{Bb}$ & $2421 \mathrm{Ab}$ & $1216 \mathrm{Bb}$ & $1175 \mathrm{Bb}$ & $1301 \mathrm{Bb}$ & $1341 \mathrm{Bb}$ \\
\hline & & & & & & & \\
\hline \multirow{2}{*}{ Bare soils } & $0-5$ & 7.8 Aa & $7.9 \mathrm{Aa}$ & $7.8 \mathrm{Aa}$ & $7.8 \mathrm{Aa}$ & 7.8 Aa & $7.9 \mathrm{Aa}$ \\
\hline & $5-15$ & 7.8 Aa & 7.6 BAb & 7.6 BAa & 7.6 ВAа & $7.4 \mathrm{Bb}$ & 7.6 BAa \\
\hline
\end{tabular}

${ }^{\dagger}$ : Soil EC averaged across depth and sampling time. Uppercase letters represent the mean separation between application rates $(p=0.05) .{ }^{++}$: Mehlich-3 extractable Ca averaged over time. Uppercase letters represent the mean separation between application rates. Lowercase letters represent the mean separation between depths $(p=0.05)$. ${ }^{+++}$: The mean $\mathrm{pH}$ from saturated paste extraction is averaged across sampling. Uppercase letters represent the mean separation between application rates within the depth. Lowercase letters represent the mean separation between depths within the application rate. $(p=0.05)$. For all cases: means with different letters are different at $p<0.05$ level among columns (uppercase letters) and rows (lowercase letters).

Copper, $\mathrm{Zn}$, and Ba were the only trace metals detected in the saturated paste extracts, with no values exceeding $1.1 \mathrm{mg} \mathrm{L}^{-1}$. This suggests that the trace metals applied with the residuals were not water-soluble and therefore relatively low bioavailability. There was no statistical difference between application rates, depths, and time of application for trace metals. Soil SAR was also not different among the application rates, soil depths, or days after application, presenting a maximum value of 3.1, which is much lower than the SAR of 13, considered the threshold for soils and plants [15]. The oading rate for TDS at the maximum application rate of 112 metric tons solid ha- was $145 \mathrm{~kg} \mathrm{ha}^{-1}$. This is well below the limit of $6724 \mathrm{~kg}$ TDS ha ${ }^{-1}$ allowed by the Oklahoma Corporation Commission (OCC) for the land application of water-base drilling mud from oil and gas exploration (Oklahoma Administrative Code 165:10-7-19). An application of only $145 \mathrm{~kg}$ of soluble salts ha ${ }^{-1}$ will not harm the soil and vegetation considering that that the resulting soil EC was only $745 \mu \mathrm{S} \mathrm{cm}^{-1}$ at $0-5 \mathrm{~cm}$ for the highest application rate. If the loading rate were considerably higher, it could harm some of the more salt-sensitive species depending on the concentration of salts already present in the receiving soil. Therefore, it may be necessary to test TDS for both the residuals and the receiving soil prior to application.

The residual applied to the plots contained an appreciable amount of M3 extractable Ca at $28,526 \mathrm{mg} \mathrm{kg}^{-1}$ (Table 1). Application rate and depth were both significant for Ca with an interaction between application rate and depth (Table 3). In the top $0-5 \mathrm{~cm}$ of soil, concentrations of M3 Ca increased with application rate with mean concentrations ranging from $1459 \mathrm{mg} \mathrm{kg}^{-1}$ for the control to $7672 \mathrm{mg} \mathrm{kg}^{-1}$ at the highest application rate of 112 metric tons solid ha ${ }^{-1}$. This particular residual would be a good soil amendment if applied to a Ca deficient and low $\mathrm{pH}$ soil [16]. 


\subsubsection{Forage}

At 110 days after HDD residuals application, there was no significant differences in forage yields for all application rates when compared to the control (data not shown). Forage yields ranged from 7.4 to 12.8 metric tons $\mathrm{ha}^{-1}$. Forage samples were also digested and analyzed for trace metals $\mathrm{Cu}, \mathrm{Zn}$, $\mathrm{Ni}, \mathrm{As}, \mathrm{Cd}, \mathrm{Cr}, \mathrm{Ba}, \mathrm{Pb}$, and $\mathrm{Co}$. The control had higher concentrations of metals compared to forage samples from treated plots, except for $\mathrm{Ni}$ and $\mathrm{Cr}$ (data not shown). Results were highly variable with no statistical significance among other application rates. Figure 1 illustrates the experimental plots right after receiving the mud and several weeks after application.
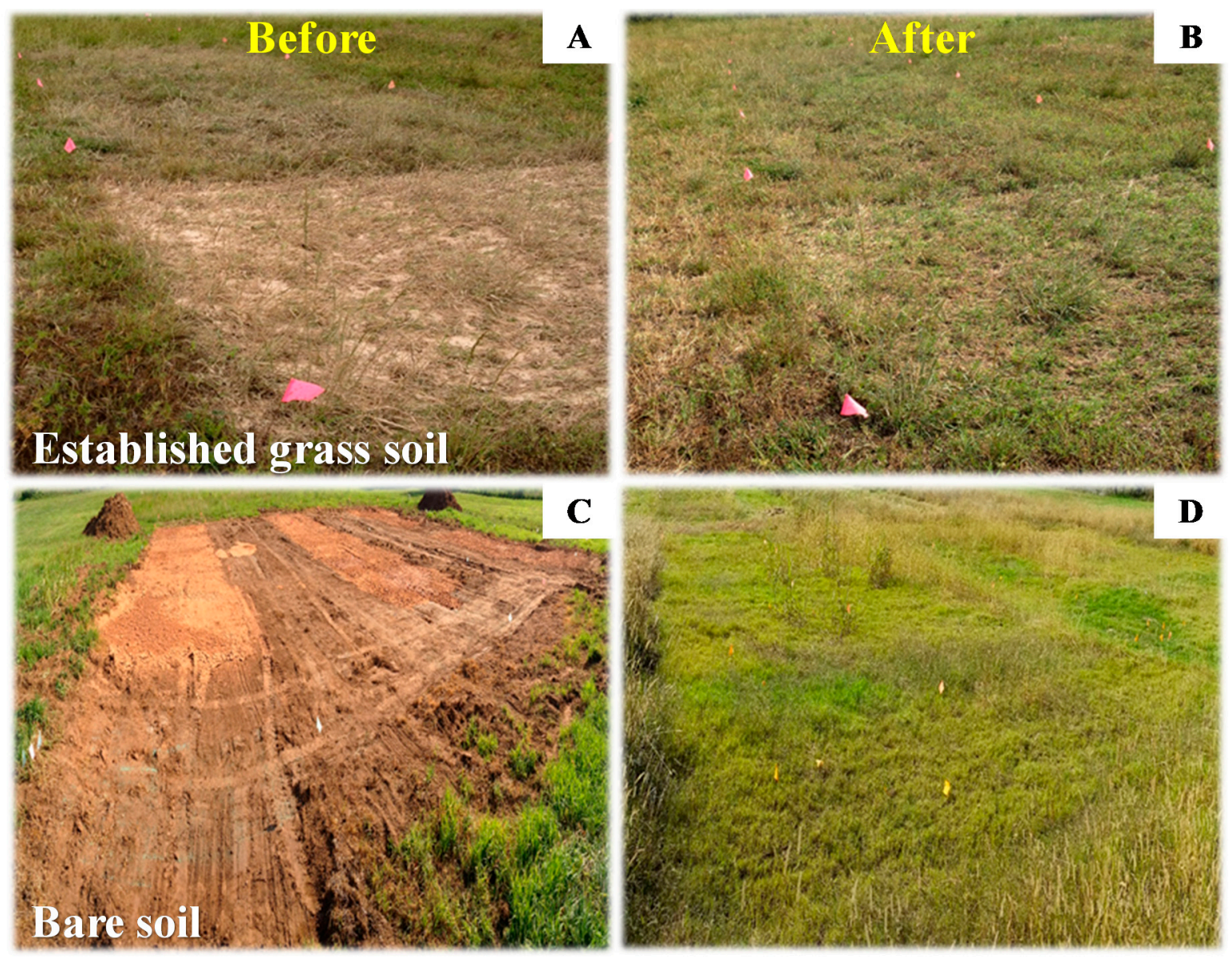

Figure 1. Experimental plots of 'established grass soil' immediately after mud application (A) and several weeks later (B); and experimental plots of 'bare soil' immediately after mud application (C) and several weeks later $(\mathbf{D})$.

\subsection{Bare Soil Plots}

\subsubsection{Soil}

Among all application rates, mean $\mathrm{pH}$ ranged from 7.8 to 7.9 in the top $0-5 \mathrm{~cm}$ and from 7.4 to 7.8 at the $5-15 \mathrm{~cm}$ depth (Table 3). The time of sampling and depth were statistically significant with an interaction between application rate and depth at $p=0.05$. With $\mathrm{pH}$ values for both residuals used in this study $\geq 8.0$, their application to an acidic soil could be beneficial. The $\mathrm{pH}$ for the majority of treated-plots in the top $0-5 \mathrm{~cm}$ was slightly higher than the 5-15 depth for both the established grass and bare soil plots (Tables 2 and 3).

The applied residuals increased the EC of the receiving soil as a function of application rate. Application rate and depth were statistically significant with two-way interaction between application rate and depth and a two-way interaction between depth and sampling time. There was also a 
three-way interaction between application rate, sampling time, and depth at $p=0.05$. Table 4 shows that soil EC increased with residuals application rate, at each sampling time. This was expected since the residuals applied (Table 1) added about $1214 \mathrm{~kg} \mathrm{TDS} \mathrm{ha}^{-1}$ at the highest rate. The highest EC value, $3545 \mu \mathrm{S} \mathrm{cm}^{-1}$, was measured at day 7 for the highest application rate. An EC of this magnitude is approaching the $4000 \mu \mathrm{S} \mathrm{cm}^{-1}$ limit for a saline soil, and could adversely affect salt-sensitive plants. Because of this high EC value, incorporation of residuals below the surface would be recommended if applying a similar residual at the 112 metric tons ha ${ }^{-1}$ application rate. Table 5 illustrates the leaching of the applied salts, as evident by a general trend of decreasing EC values with time in the surface $0-5 \mathrm{~cm}$ depth, concurrent with an increasing trend at the subsurface $5-15 \mathrm{~cm}$ depth. This was expected because of the ample amount of precipitation received; $10.14 \mathrm{~cm}$ rainfall within a 22-day time period combined with the lack of transpiration since the plant was just beginning to become established. This trend was not as obvious between days 29 and 96 . EC actually increased in the top $0-5 \mathrm{~cm}$ layer in the control and at the application rates of 22 and 112 metric tons solid ha ${ }^{-1}$, although not significantly (Table 5). During this 67-day time period, only $16.03 \mathrm{~cm}$ was received with an average temperature well into the $32.2{ }^{\circ} \mathrm{C}$, so this is likely a result of wicking salts up through the soil profile as soil moisture was evaporated and transpired as the plant developed.

There was no statistical difference between application rates, depth, or sample time with respect to trace metals measured in soil saturated paste extracts. Concentrations for Ba were all less than $1.0 \mathrm{mg} \mathrm{L}^{-1}$ and all other metals were $\leq 0.05 \mathrm{mg} \mathrm{L}^{-1}$. The maximum mean value for SAR was 7.8 at the $5-15 \mathrm{~cm}$ depth for the control. Application rate and depth were both significant for SAR with an interaction between application rate and depth (Table 6). As expected, increasing the application rate resulted in a greater SAR at the $0-5 \mathrm{~cm}$ depth. Notice that the SAR was greater for bare soil plots that received residuals compared to the established grass plots; this was due to the higher SAR content in the residuals applied to the bare soil plots (Table 1). SAR values observed in this field study are of little concern with a loading rate of only $429 \mathrm{~kg} \mathrm{ha}^{-1} \mathrm{Na}$ when applied at the highest application rate of 112 metric tons of solid ha ${ }^{-1}$. However, applying the same residual with a SAR of 19 to a soil that already has a high SAR would likely have negative implications. A soil is considered 'sodic' when the $\mathrm{SAR} \geq 13$, the $\mathrm{EC}<4000 \mu \mathrm{S} \mathrm{cm}^{-1}$, and the $\mathrm{pH}>8.5$. A 'saline-sodic' soil has a SAR $\geq 13$, an EC $>4000 \mu \mathrm{sm}^{-1}$, and a $\mathrm{pH}<8.5$. Sodic soils typically have poor structure and tend to crust, restricting water infiltration [17]. High concentrations of $\mathrm{Na}$ compete with plant-available $\mathrm{Ca}$ and $\mathrm{Mg}$ which can limit plant growth. An application of a high SAR residual to bare soil with no incorporation could create a thin dispersed layer at the surface, which could inhibit the germination of seed and also inhibit the infiltration of water.

Table 4. Soil electrical conductivity $\left(\mathrm{EC}, \mu \mathrm{S} \mathrm{cm}{ }^{-1}\right)$ from saturated paste extracts as a function of sampling depth, residual application rates, and sampling time (days after application of residuals) to bare soil.

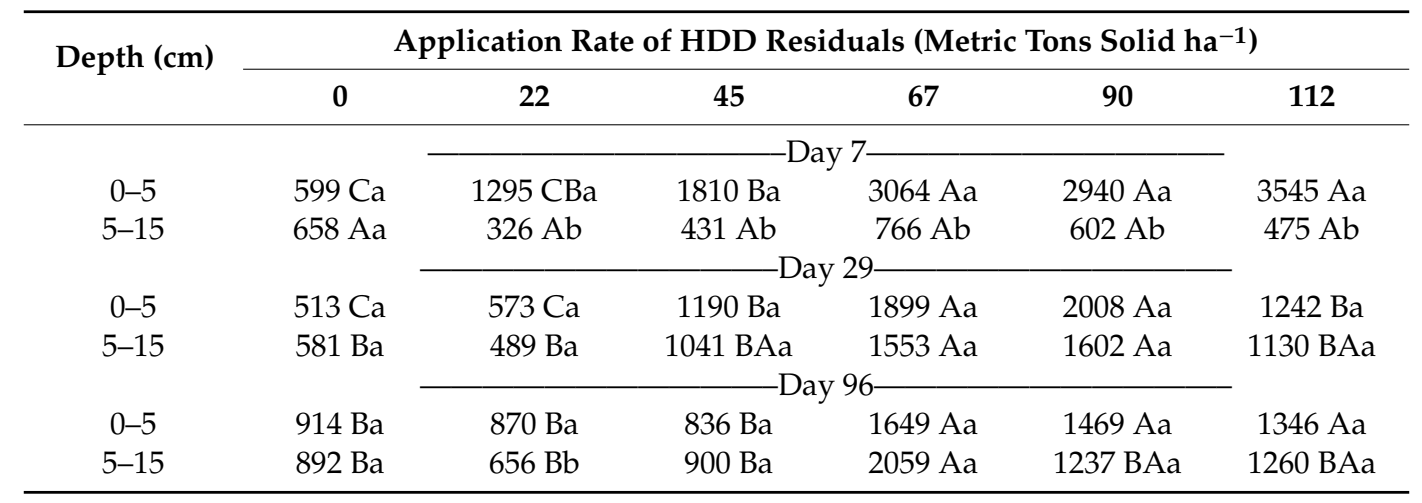

Uppercase letters represent the mean separation between application rates within the depth. Lowercase letters represent the mean separation between depths within the application rate $(p=0.05)$. Means with different letters are different at $p<0.05$ level among columns (uppercase letters) and rows (lowercase letters). 
Table 5. Comparison of electrical conductivity $\left(\mathrm{EC}, \mu \mathrm{S} \mathrm{cm}^{-1}\right)$ from saturated paste extracts among days after HDD residual application to bare soil at six application rates and two sampling depths.

\begin{tabular}{cccc}
\hline Application Rate & Day $\mathbf{7}$ & Day 29 & Day 96 \\
\hline (metric tons solid ha $^{\mathbf{- 1}}$ ) & $599 \mathrm{~B}$ & $-0-5 \mathrm{~cm}$ & \\
0 & $1295 \mathrm{~A}$ & $513 \mathrm{~B}$ & $914 \mathrm{~B}$ \\
22 & $1810 \mathrm{~A}$ & $573 \mathrm{~B}$ & $870 \mathrm{BA}$ \\
45 & $3064 \mathrm{~A}$ & $1190 \mathrm{~B}$ & $836 \mathrm{C}$ \\
67 & $2940 \mathrm{~A}$ & $2008 \mathrm{~B}$ & $1649 \mathrm{~B}$ \\
90 & $3545 \mathrm{~A}$ & $1242 \mathrm{~B}$ & $1469 \mathrm{~B}$ \\
112 & & $-5-15 \mathrm{~cm}$ & $1346 \mathrm{~B}$ \\
& $658 \mathrm{~A}$ & $581 \mathrm{~A}$ & $892 \mathrm{~A}$ \\
0 & $326 \mathrm{~B}$ & $489 \mathrm{BA}$ & $656 \mathrm{~A}$ \\
22 & $431 \mathrm{~A}$ & $1041 \mathrm{~A}$ & $900 \mathrm{~A}$ \\
67 & $766 \mathrm{~B}$ & $1553 \mathrm{BA}$ & $2059 \mathrm{~A}$ \\
90 & $602 \mathrm{~A}$ & $1602 \mathrm{~A}$ & $1237 \mathrm{~A}$ \\
112 & $475 \mathrm{~B}$ & $1130 \mathrm{~A}$ & $1260 \mathrm{~A}$ \\
\hline
\end{tabular}

Uppercase letters represent the mean separation between days within application rate and depth $(p=0.05)$. Means with different letters are different at $p<0.05$ level among columns (uppercase letters) and rows (lowercase letters).

Table 6. Mean sodium absorption ratio (SAR, by saturated pasted extract) of soils treated with HDD residuals at six application rates. Soil SAR values averaged across three sampling times.

\begin{tabular}{ccccccc}
\hline \multirow{2}{*}{ Depth (cm) } & \multicolumn{5}{c}{ Application Rate of HDD Residuals (Metric Tons Solid ha ${ }^{-\mathbf{1}}$ ) } \\
\cline { 2 - 6 } & $\mathbf{0}$ & $\mathbf{2 2}$ & $\mathbf{4 5}$ & $\mathbf{6 7}$ & $\mathbf{9 0}$ & $\mathbf{1 1 2}$ \\
\hline $0-5$ & $3.8 \mathrm{CBb}$ & $2.0 \mathrm{Ca}$ & $4.2 \mathrm{Ba}$ & $7.3 \mathrm{Aa}$ & $7.7 \mathrm{Aa}$ & $6.3 \mathrm{Aa}$ \\
$5-15$ & $7.8 \mathrm{Aa}$ & $0.8 \mathrm{Cb}$ & $2.1 \mathrm{BCb}$ & $6.1 \mathrm{BAa}$ & $5.0 \mathrm{BACa}$ & $1.4 \mathrm{Cb}$ \\
\hline
\end{tabular}

Uppercase letters represent the mean separation between application rates and lowercase letters represent the mean separation between depths $(p=0.05)$. Means with different letters are different at $p<0.05$ level among columns (uppercase letters) and rows (lowercase letters).

When applied at the maximum application rate of 112 metric tons of solid ha ${ }^{-1}$, TDS loading was $1214 \mathrm{~kg} \mathrm{ha}^{-1}$. This is much higher than the residuals applied to the established grass plots, but still well below the OCC threshold of $6724 \mathrm{~kg} \mathrm{ha}^{-1}$ for the land application of water-based oil and gas drilling mud. If the receiving soil had high salt concentrations before application, this loading rate could have the potential to make the receiving soil 'saline'; therefore, it is ideal to test soils prior to HDD application.

Compared to the residual applied to the established grass plots, there was less M3 extractable Ca in the residual applied to the bare soil plots. Additionally, the M3 extractable Ca was not different between application rates, depth, or sampling time due to the low number of base cations applied.

\subsubsection{Forage}

Twenty-nine days after residuals application to bare soil plots seeded with bermudagrass, percent ground cover was not significantly different from the un-amended control compared to any treatment. At day 63, the mean percent cover for plots receiving the lowest application rate of residual applied (22 metric tons solid ha ${ }^{-1}$ ) was $75 \%$ and was significantly higher than that of the control at $57 \%$ (Figure 2). The mean percent cover for plots receiving the highest application rate was $44 \%$ and was significantly lower than the control. Growth in all plots was much faster between days 30 and 63 than days 0 and 30 (Figure 3). The significant increase in percent grass cover on day 63 suggests two things: first, a lower application rate of residuals at 22 metric tons of solid ha ${ }^{-1}$ might aid in the germination of bermudagrass seed. Second, at the highest application rate of 112 metric tons of solid $\mathrm{ha}^{-1}$, applied residuals possibly hinder germination. All other application rates were not significantly 
different from the control. The cover consisted of nearly $100 \%$ bermudagrass. One explanation for the increase in germination at the lowest application rate is that the residuals provided some cover to the seeds used to establish the grass. By applying a small amount of residual to the exposed surface seed, the seed is essentially being buried or incorporated, unlike the control. The seed is also receiving a source of water with the residual application compared to the control. Low application rates of the residual may have improved water retention in the thin layer where the seeds were located. Low germination at the highest application rate could be a result of the seed being excessively buried at too great a depth. After drying, a layer of clay from the residual application could be difficult for germinating seedlings to penetrate if it is excessively deep. Figure 1 illustrates the experimental plots right after receiving the mud and several weeks after application.

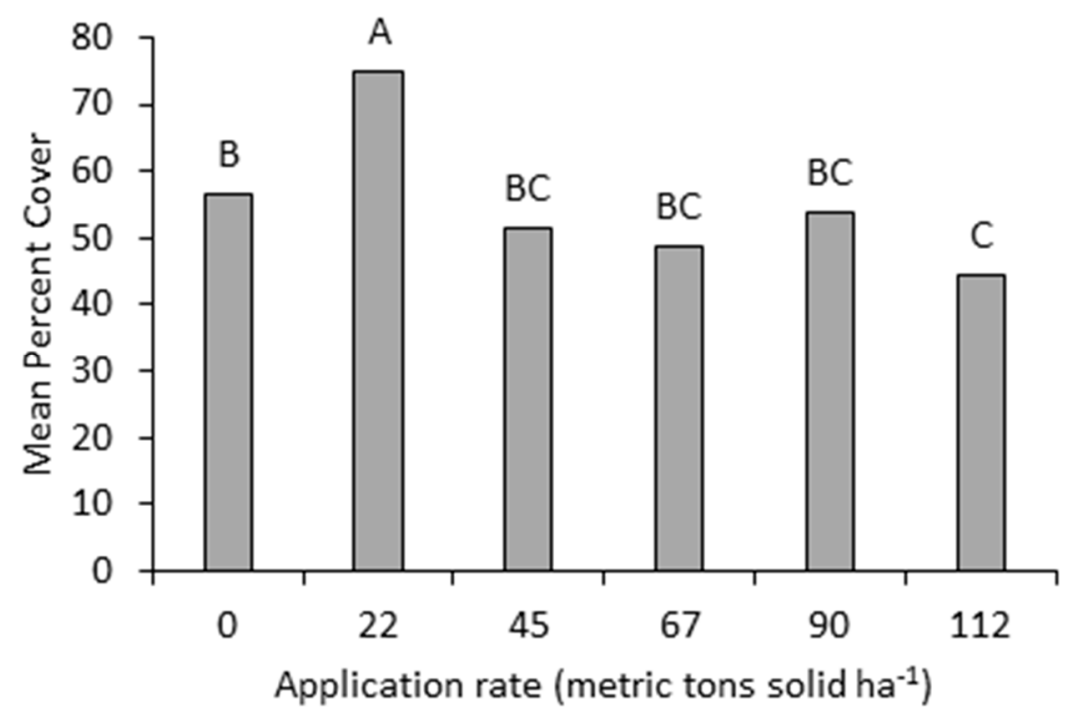

Figure 2. Mean percent cover of bare soil plots 63 days after residual application. Upper case letters represent the mean separation between application rates. Bare soil was seeded with bermudagrass seed before residual application.

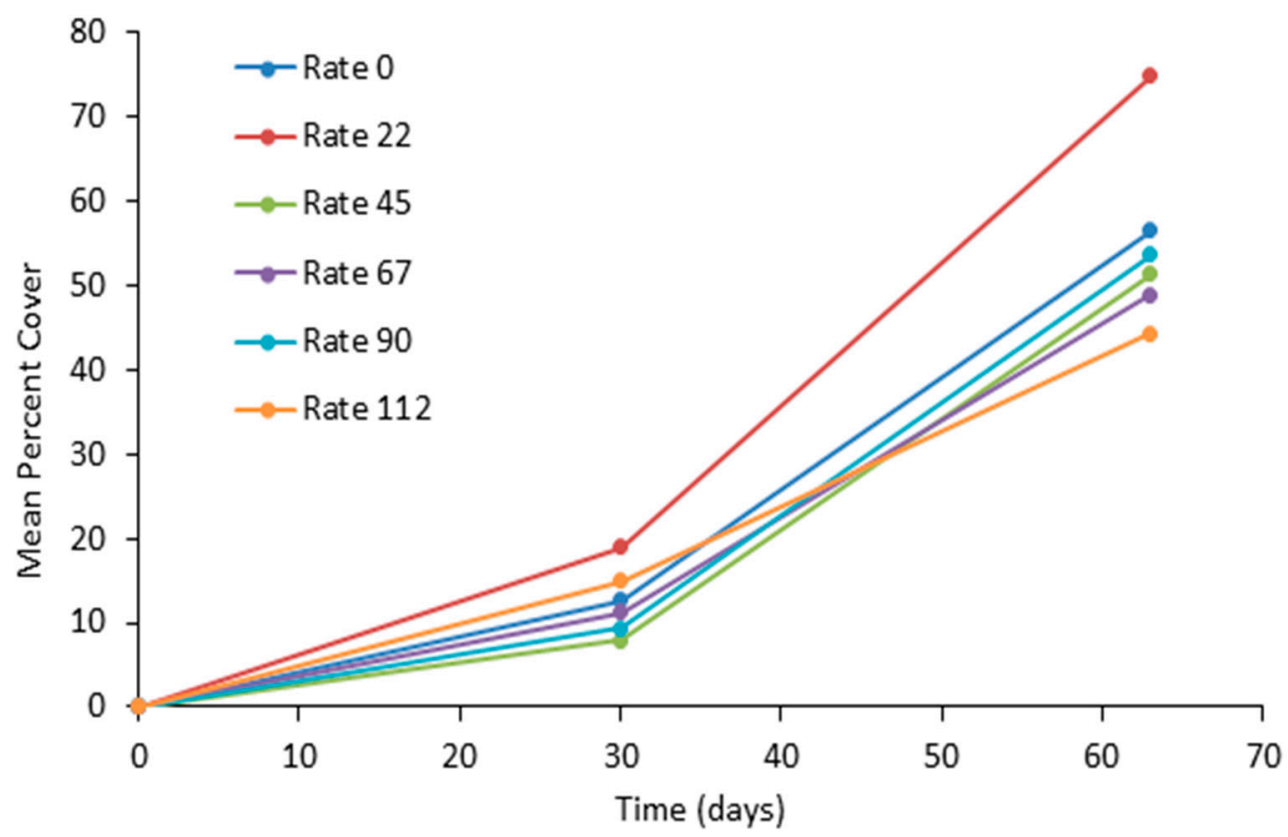

Figure 3. Mean percent cover for HDD residual application rates of $0,22,45,67,90$, and 112 metric tons solid $\mathrm{ha}^{-1}$ to bare soil plots. Measured at days 30 and 63. 


\section{Recommendations and Implications}

The land application of any by-product must be conducted in a manner that is sustainable and not harmful to the environment or human health. To do this properly the physical and chemical limiting factors should be known, which may be specific to each HDD residual material. For the two HDD residuals used in these field studies, the most limiting factor was the amount of total solids applied as pointed out in the previous study [13]. However, the limiting factor for land application of HDD residuals could vary depending on where the boring is taking place. If boring takes place at a site with historic heavy metal contamination, metal concentrations would likely be the most limiting factor for land application. For this reason, testing the residual when boring through a known contaminated site is highly recommended.

An increase in soil $\mathrm{pH}$ in the top 0-5 $\mathrm{cm}$ was observed in both field studies. Soda ash (sodium carbonate) is a common additive used in HDD fluids in order to increase the removal of soil cuttings. However, not all residuals are alkaline as observed in the survey study [13]. In the survey study [13], the $\mathrm{pH}$ of the 58 residuals ranged from 4.7 to 10.0, while those selected for this study were 8 and 8.2 for the bare soils and the established grass plots, respectively (Table 1), with the soil $\mathrm{pH}$ ranging from 6.3 to 8 depending on the soil sample depth, rate of residual applied, and time after the residual application (Table 2). Thus, any potential to increase $\mathrm{pH}$ in the top $0-5 \mathrm{~cm}$ of soil with the application of HDD residuals would vary depending on the residual being applied, and any long term effect would depend on the receiving soil's buffering capacity and organic matter content.

In both field studies, EC increased in the top $0-5 \mathrm{~cm}$ as the application rate increased. Therefore, a residual's EC could potentially be a limiting factor. This is especially true if the receiving soil's EC is already high prior to application. Application rates exceeding the rate of 112 metric tons solid ha ${ }^{-1}$ could potentially be harmful to salt-sensitive plants depending on the residual's EC as well as the EC of the soil receiving the amendment.

The application of a residual with a high concentration of water-soluble metals, in the context of aquatic life or drinking water criteria, does not necessarily mean that they would remain water-soluble after application to the soil. Depending on the mineralogy, organic matter content, and $\mathrm{pH}$ of the receiving soil, the constituents would be retained by the soil through several processes such as ligand exchange/chemisorption, precipitation, or ion exchange [18], thus making them mostly unavailable for plant uptake. Results from the digestion of forage from the established grass plots imply that nothing added was bioavailable because concentrations of almost all metals were higher in the control than plots receiving HDD residuals.

As observed for the M3 extracts from the residuals applied to the established grass plots, HDD residuals have the potential to be a source of secondary plant nutrients ( $\mathrm{Ca}, \mathrm{Mg}$ and $\mathrm{S}$ ). This will vary depending on the source of the residual and the nature of soil where boring took place. Other nutrients including $\mathrm{P}$ and $\mathrm{K}$ and some micronutrients can also contribute to the receiving soil, but $\mathrm{N}$ is typically low.

For this study, application rates up to 112 metric tons solid ha ${ }^{-1}$ had no significant impact on forage yield from the established grass plots. Applying at rates higher than 112 metric tons solid ha ${ }^{-1}$ to plants that have low height could possibly retard forage and turf yield as a result of smothering the plant. This was not observed for the established grass plots in this study since the grass was already at a height of around $15 \mathrm{~cm}$ prior to application. Another possible problem with the over-application of solids is that a thick clay layer could seal off the soil causing poor water infiltration and crusting, both of which will hinder plant growth. For the scenario of a bare receiving soil where seed germination is desired, the solids application rates becomes more critical since a germinating seed is much more sensitive than an established plant. For this study, the application of solids at 112 metric tons solid $\mathrm{ha}^{-1}$ significantly reduced the germination rate compared to the unamended control. As a result, exceeding application rates of 112 metric tons solid ha ${ }^{-1}$ is not recommended on bare soils where seed germination is desired. However, based on the results of this study, a low application rate of solids ( 22 metric tons solid ha ${ }^{-1}$ ) can be beneficial to the germination of bermudagrass seed, thus making the 
HDD residuals valuable for such purposes. Recommended application rates, based only on solids, should be $\leq 90$ metric tons solid ha ${ }^{-1}$ for bare soils receiving HDD residuals. Similarly, the SAR of the HDD residual applied is also an important consideration along with the type of cover, and this may dictate management and application rates. For example, a residual with an excessive SAR is not likely to cause a problem when applied to an established forage. However, a high SAR residual could cause problems for bare soils as previously described, even at low application rates; this problematic situation could be prevented by incorporating the residual into the soil instead of leaving un-incorporated on the surface. For this study, the application of a residual with a SAR of 19 to bare soil was not a problem for seed germination until application rates reached 112 metric tons of solid ha ${ }^{-1}$.

This study did not fully characterize the HDD residues as their physical properties such as the particle size distribution of the solid portion contained in the residuals. Therefore, since $44 \%$ of the U.S. soils have clay-enriched horizons [19] and most of them are covering the area crossing the 26 states from where the HDD residues were obtained, future research is encouraged to verify the particle size distribution of the solid portion of the residues, so that no negative impacts occur on the receiving land. Moreover, there is a higher clay content in some residues since, as previously mentioned, HDD residues contain bentonite clay, a 2:1 soil mineral. As a matter of fact, 90 to 112 metric tons of solid ha ${ }^{-1}$ of enriched-clay material will have a very different impact compared to 90-112 metric tons of solid ha ${ }^{-1}$ of enriched-sandy material. For example, based on the soil particle size distribution, the coarser the particle, the higher the plastic viscosity of the HDD residue [20]. This is because silt and clay generally dissolve into the drilling fluid, whereas sand particles are suspended [20]. However, soils overall present a wide range of particle size distribution, where sand, silt, and clay vary from 74 to 440,2 to 74 , and 0.5 to $2 \mu \mathrm{m}$, respectively, while colloids have a diameter of $<0.5 \mu \mathrm{m}$ [21]. Thus, if the results are to have any generality, the soil/solids particle size distribution should be considered in future studies.

Supplementary Materials: The following are available online at http://www.mdpi.com/2071-1050/12/24/10264/s1.

Author Contributions: Conceptualization, J.D. and C.P.; methodology, J.D. and C.P.; validation, J.D., C.P., J.A. and H.Z.; formal analysis, J.D., J.A. and H.Z.; investigation, J.D. and C.P.; resources, C.P. and H.Z.; data curation, J.D., C.P., J.A. and H.Z.; writing-original draft preparation, J.D.; writing-review and editing, J.A.; visualization, J.A.; supervision, C.P.; project administration, C.P. and H.Z.; funding acquisition, C.P. All authors have read and agreed to the published version of the manuscript.

Funding: This work was supported by the Oklahoma Agricultural Experiment Station.

Conflicts of Interest: The authors declare no conflict of interest.

\section{References}

1. Brisolara, K.B.; Gentile, B.; Puszykowski, K.; Bourgeois, J. Residuals, sludge, and biosolids: Advancements in the field. Water Environ. Res. 2020, 92, 1541-1551. [CrossRef] [PubMed]

2. Whalen, J.K.; Chang, C.; Clayton, G.W.; Carefoot, J.P. Cattle manure amendments can increase the pH of acid soils. Soil Sci. Soc. Am. J. 2000, 64, 962-966. [CrossRef]

3. Clements, K.; Veil, J.A.; Leuterman, A.J. Global practices and regulations for land application and disposal of drill cuttings and fluids. In SPE International Conference on Health, Safety and Environment in Oil and Gas Exploration and Production; Society of Petroleum Engineers: Rio de Janeiro, RJ, Brazil, 2010.

4. Bauder, T.A.; Barbarick, K.A.; Ippolito, J.A.; Shanahan, J.F.; Ayers, P.D. Soil properties affecting wheat yields following drilling-fluid application. J. Environ. Qual. 2005, 34, 1687-1696. [CrossRef] [PubMed]

5. Singh, R.; Agrawal, M. Potential benefits and risks of land application of sewage sludge. Waste Manag. 2008, 28, 347-358. [CrossRef] [PubMed]

6. Girovich, M.J. Biosolids Treatment and Management: Processes for Beneficial Use; Dekker: New York, NY, USA, 1996.

7. Guo, M. Disposal of biosolids through land application: Concerns and opportunities. J. Waste Water Treat. Anal. 2012, 3, e104. [CrossRef]

8. Jala, S.; Goyal, D. Fly ash as a soil ameliorant for improving crop production-A review. Bioresour. Technol. 2006, 97, 1136-1147. [CrossRef] [PubMed] 
9. Nihalani, S.A.; Mishra, Y.D.; Meeruty, A.R. Handling and utilisation of fly ash from thermal power plants. Circ. Econ. Fly Ash Manag. 2019, 1-11. [CrossRef]

10. Adriano, D.C.; Weber, J.T. Influence of fly ash on soil physical properties and turfgrass establishment. J. Environ. Qual. 2001, 30, 596-601. [CrossRef] [PubMed]

11. Sajwan, K.; Paramasivam, S.; Alva, A.; Adriano, D.; Hooda, P. Assessing the feasibility of land application of fly ash, sewage sludge and their mixtures. Adv. Environ. Res. 2003, 8, 77-91. [CrossRef]

12. Jegadeesan, G.; Al-Abed, S.R.; Pinto, P. Influence of trace metal distribution on its leachability from coal fly ash. Fuel 2008, 87, 1887-1893. [CrossRef]

13. Daniel, J.; Penn, C.; Antonangelo, J.; Zhang, H. Physicochemical characterization of horizontal directional drilling residuals. Sustainability 2020, 12, 7707. [CrossRef]

14. Mehlich, A. Mehlich 3 soil test extractant: A modification of Mehlich 2 extractant. Commun. Soil Sci. Plant Anal. 1984, 15, 1409-1416. [CrossRef]

15. Turner, J.C.; Hattey, J.A.; Warren, J.G.; Penn, C.J. Electrical conductivity and sodium adsorption ratio changes following annual applications of animal manure amendments. Commun. Soil Sci. Plant Anal. 2010, 41, 1043-1060. [CrossRef]

16. Zhang, H.; Raun, B. Oklahoma Soil Fertility Handbook; Department of Plant and Soil Sciences, Oklahoma Agricultural Experiment Station, Oklahoma Cooperative Extention Service, Division of Agricultural Sciences and Natural Resources, Oklahoma State University: Stillwater, OK, USA, 2006.

17. Davis, J.G. Managing Sodic Soils; Colorado State University Cooperative Extension: Fort Collins, CO, USA, 2003.

18. Essington, M.E. Soil and Water Chemistry: An Integrative Approach; CRC Press: Boca Raton, FL, USA, 2015.

19. Bockheim, J.; Hartemink, A. Distribution and classification of soils with clay-enriched horizons in the USA. Geoderma 2013, 209-210, 153-160. [CrossRef]

20. Sun, P.; Mo, D.; Ariaratnam, S.T.; Cao, H.; Zhang, P. Laboratory study of fluid properties owing to cutting intrusions during horizontal directional drilling. Undergr. Space 2020, 5, 20-29. [CrossRef]

21. Sullivan, D. Understanding Drilling Fluids Solids Control with Horizontal Directional Drilling Rigs. Available online: https:/www.trenchlesspedia.com/understanding-drilling-fluids-solids-control-withhorizontal-directional-drilling-rigs/2/4163 (accessed on 4 December 2020).

Publisher's Note: MDPI stays neutral with regard to jurisdictional claims in published maps and institutional affiliations.

(C) 2020 by the authors. Licensee MDPI, Basel, Switzerland. This article is an open access article distributed under the terms and conditions of the Creative Commons Attribution (CC BY) license (http://creativecommons.org/licenses/by/4.0/). 